\title{
Ludmiła Sadko
}

Państwowy Uniwersytet w Brześciu

im. A.S. Puszkina

https://orcid.org/0000-0001-5880-1570

\section{Малыя і мінімальныя лірычныя формы ў беларускай і замежнай літаратурах: гісторыка-культурная перспектыва}

Функцыянаванне мастацкага тэксту ў гісторыка-культурным кантэксце падпарадкавана, разам з іншымі законамі, сістэмнаму прынцыпу моўнай і маўленчай эканоміі, інтэнцыі да лаканічнасці і дакладнасці данясення інфармацыі. У розныя эпохі ад старажытнасці да сучаснасці асіметрыя паміж планам зместу і планам выяўлення ў творы, асабліва ўласцівая лірычным формам мастацкага тэксту, нярэдка праяўляе сябе праз нявыяўленасць, непрадстаўленасць некаторых адзінак на розных узроўнях выказвання (лексічным, граматычным, сінтаксічным і г.д.). Мэта дадзенага даследавання - вызначэнне этапаў фарміравання эстэтыкі і паэтыкі малых і мінімальных лірычных формаў у беларускай і замежнай літаратурах у гісторыка-культурнай перспектыве, ад даўніны да сучаснасці.

У антычны перыяд малыя і мінімальныя лірычныя формы былі запатрабаваныя ў творчасці старажытных грэкай і рымлян - Эўрыпіда, Менандра, Вяргілія, Аўсонія і Марцыяла. Монаверш меў распайсюджанне і у наступныя эпохі літаратурна-мастацкага развіцця. У рускай літаратуры тэндэнцыі да мінімалізацыі сустракаюцца ў творчасці I. Хемніцэра, чые аднарадкоўі, створаныя па правобразе афарызма, ператварыліся з часам у прыказкі і прымаўкі, якія выкарыстоўваюцца цяпер без пазначэння аўтарства («Большому кораблю и плаванье большое»). Варыянт мініяцюры-эпітафіі ёсць і $\breve{y}$ творчасці М. Карамзіна («Покойся, милый прах, до радостного утра»).

Адзначым, што прынцыпы мінімалізацыі тэксту, кампрэсіі яго частак асаблівым чынам праяўляюць сябе ў беларускай літаратуры 
ўжо на этапе яе фарміравання. Праблемы адаптацыі вялікай колькасці перакладных багаслоўскіх тэкстаў у старажытнарускай і старажытнабеларускай літаратурах прымушаюць перакладчыкаў таго часу звяртацца да сродкай трансляцыі іншамоўных тэкстаў менавіта з дапамогай прыёмаў кампрэсіі. Для таго, каб зрабіць тэкст зразумелым і блізкім, пры перакладзе з грэчаскай, лацінскай і іншых мой змяняўся парадак слоў, уводзіліся знаёмыя айчыннаму чытачу дэталі побыту, выключаліся незразумелыя эпізоды, замяняліся сродкі метафарызацыі і фразеалагічныя адзінкі. Так, напрыклад, Францыск Скарына ў прадмове да кнігі «Зыход» звяртаецца да перакладу дзесяці Майсеевых запаведзяў, адаптуючы іх для чытача-беларуса, адрасуючы «людем посполитым к доброму научению»:

Веруй в Бога единаго!

А не бери надармо имени его!

Помни дни светые святити!

Отца и матку чтити!

Не забивай ни едина!

И не делай грђхху блудна!

Не вкради, что дружнего!

А не давай сведецства лживага!

Не пожедай жены ближнего!

Ни имения или речи его! ${ }^{1}$

Лаканічнасць формы, безумоўна, зададзена ўжо біблейскім тэкстам, аднак Ф. Скарына ўдала перадаў афарыстычнасць, ёмістасць і ўніверсальнасць выказвання-асновы сродкамі роднай мовы. Гэты тэкст па праве можа лічыцца адным з першых узораў, дзе вытрыманы этна- і сацыяспецыфічныя нормы, а таксама прадстаўлены варыянт рыфмойкі на старабеларускай мове, зразумелай шырокаму колу чытачоў свайго часу. У дадзеным выпадку мінімізацыя тэксту прадыктавана патрабаваннямі афарыстыкі як жанру. Яшчэ адно лірычнае выказванне Ф. Скарыны 3 прадмовы да кнігі «Эсфір» (1519) таксама будуецца па прынцыпе лаканічнай перадачы высокаканцэнтраванай інфармацы:

Не копай под другом своим ямы,

Сам въвалишся в ню.

Не став Амане Мардохею шибинице,

Сам повисьнеш на ней ${ }^{2}$.

1 Ф. Скарына, Творы: Прадмовы, сказанні, пасляслойі, акафісты, пасхалія, Мінск 1990 , с. 53.

2 Тамсама, с. 71. 
У дадзеным лаканічным тэксце змяшчаецца і дыдактычнае павучанне, прадстаўленае $\ddot{y}$ афарыстычнай мастацкай форме, і перададзена інфармацыя пра частку пурымскай гісторыі яўрэяў, пра складаныя уззаемаадносіны Мардэхая і Амана, які паплаціўся за свае інтрыгі ганебнай смерцю.

Культура антычнай эпіграфікі, адной з малых і мінімальных лірычных формаў, ярка праявіла сябе ў творчасці Андрэя Рымшы, які стварыў тры прыклады эпіграм на гербы вялікалітоўскіх магнатаў (Л. Сапегі, Я. Валовіча, Ф. Тышкевіча). Згодна з барочнай традыцыяй выкарыстання яркіх метафар складае свой тэкст А. Рымша, славячы гербы Сапегаў (1588), адзначаючы воінскую мужнасць і чалавечую годнасць прадстаўнікой гэтага роду. Вось як заканчвае прысвячэнне на старабеларускай мове паэт:

Живете ж Сапегове, вси в многие лета,

Ваша слава слыть будеть, покуль станеть света,

Подавайте ж потомком, што маете з предков,

Ведь же и ваших цных справ ввесь свет полон светков ${ }^{3}$.

У гэтым урыўку ў лапідарным стылі адлюстраваны аснойныя рысы героіка-эпічных апавяданняў, таленавіта мінімалізаваныя паэтам да памераў малой лірычнай формы.

Ігнат Легатовіч, ураджэнец Гродзеншчыны, у 1848 годзе выдаў зборнік «Эпіграмы». Творы былі напісаныя на польскай мове і мелі вялікую папулярнасць у грамадстве таго часу. Мініяцюры Легатовіча змяшчалі ад двух да дванаццаці радкой і заснойваліся на сродках катэгорыі камічнага. Сатыры падвяргаліся як сацыяльныя, так і асобасныя заганы - жорсткасць, прагнасць, грубасць, глупства і г. д.:

Павел-лекар без сумнення

Не жыве з таго ӱжо лета;

Ён памёр, як збаўца света,

Дзеля нашага ўцалення ${ }^{4}$

(пераклад У. Мархеля)

Найбольшую вядомасць набыла кароткая эпіграма, якая з'явілася на смерць жорсткага памешчыка:

3 Старажытная беларуская літаратура (XII-XVII cmст.), Мінск 2007, с. 243.

4 Гл.: М. Хаўстовіч, Гісторыя беларускае літаратуры 30-40-x г2. XIX cm., Мінск 2001, c. 49 . 
Са смерцю Оштарпа ўсё інакшым стане:

Панове кінуць піць,

Пачнуць есці сяляне ${ }^{5}$.

(пераклад К. Цвіркі)

У творах I. Легатовіча праяўляецца тэндэнцыя да завастрэння думкі і лаканічнай гульні слой у апошнім радку. Такі падыход - падахвочванне чытача да дэшыфроўкі, сааўтарства, моўнай гульні з'яўляецца адным з запатрабаваных у тэкстах-мініяцюрах і на сучасным этапе.

У XX стагоддзі малыя і мінімальныя лірычныя тэксты працягваюць заставацца дастаткова рэдкай, але сістэмнай з'явай, у беларускай і сусветнай літаратуры назапашаны значны корпус мастацкіх тэкстаў, заснаваных на прынцыпе мінімізацыі выказвання.

У замежнай літаратуры французскі паэт Гіём Апалінэр у 1913 годзе $\breve{y}$ кнізе «Алкаголі» змясціў вядомы тэкст-аднарадкойе «И одинокий звук единственной струны», які стаў класічным узорам падобнай паэзіі на сучасным этапе. Рускі аўтар В. Брусаў ажно ў 1895 годзе стварае эксперыментальны тэкст «О закрой свои бледные ноги». Васіліск Гнядоӱ у зборніку «Смерць мастацтву. Пятнаццаць (15) паэм» у 1913 годзе звяртаецца для стварэння мінімалізаванай лірычнай формы да магчымасцяў мудрагелістай мовы («Бубчиги Козлевая - Сиреня. Скрымь Солнца») і да эксперыментаў з адналітарным тэкстам $(\ll$ Паэма $14 \gg: \ll Ю »)$.

У беларускай літаратуры у 1915 годзе, дзякуючы творчым пошукам М. Багдановіча, з'яўляецца першы ўзор монастрофа у жанры танка. У вершы таленавіта і дакладна перададзеныя як асаблівасці фармальнай арганізацыі танка, так і філасафічная ёмістасць найлепшых узорай гэтага жанру:

Ax, як спявае

Сінявокая птушка

Ў муках кахання.

Сціхні, птушачка, сціхні,

Каб не тамілася ${ }^{6}$.

Беларускі паэт-маладняковец А. Александровіч у 1926 годзе ў кнізе «Прозалаць» стварае некалькі эксперыментальных тэкстаў, што

\footnotetext{
5 Тамсама, с. 50.

6 Сайт Максіма Багдановіча [Электронны рэсурс], Рэжым доступа http https:// www.maksimbogdanovich.ru/stories/286.htm, Дата доступа 12.09.2019.
} 
звыкла трактуюцца як праявы візуальнай паэзіі і канонаў футурызму. Аднак дадзены верш можа быць разгледжаны як мінімалістычны тэкст-аднарадкоўе, які разгортваецца не злева направа, а зверху ӱніз, як гэта магчыма ва ўсходніх традыцыях пісьма. Такому чытанню гэтага твора спрыяе таксама практычна поўнае скасаванне знакаў прыпынку і вялікіх літар:

о
мне
ісьці
вясьне
паклонам
слаць прывет
о мы ў жыцьці
вітаць чырвоны
сонца новы сьвет.
Беларусь вясна цябе
у з б а г а ц і л а д о л я й
сонцам сілы ў б а р а ц ь б е
н а п о у н і і л а п а д п о л ь л е
П ры в е т в я с ьн е, прыво л ь лю

У беларускай літаратуры ў 1960-я гады Алесь Наўроцкі, паэт-дысідэнт, эксперыментатар, выдае зборнікі «Неба ўсміхаецца маланкаю» i «Гарачы снег». Зварот да элементаў абсурдысцкай паэтыкі, выкарыстанне знарок зніжанай інтанацыі, імкненне адлюстраваць вобраз моўнай і сітуатыўнай штодзённасці, пазбаўленай якой бы там ні было героікі, пафаснасці і вонкавай лірычнасці, ляжаць у аснове стратэгіі пісьма А. Наўроцкага. Верш «Вясновыя думкі» уяяўляе сабой цыкл 3 шасці двухрадкойяў, толькі першае з якіх адпавядае ўласна лірычнаму канону. Наступныя двухрадкойі служаць антытэзай, па-асабліваму развіваюць заяўленую ў загалоўку тэму вясновых роздумаў. Верш становіцца кпінамі з падманутых чытацкіх чаканняў:

I

У бярэзніку, дзе заціхае вецер-узвей, Жыве на галінцы салавей.

II

На дрывотні - закінуты, заржавелы як след, Жыве нікому не патрэбны веласіпед.

7 А. Александровіч, Прозалащь: вершы, Менск 1926, с. 31. 
III

У суседкі на твары жыве нос кірпаты,

Я за ім назіраю з акна сваёй хаты.

IV

I ў душы маёй, мне назло,

Каханне да гэтага носу ажыло.

$\mathrm{V}$

Эх, вясна, ты, вясна, адна прыгажосць!

Усе элементы кахання ёсць.

VI

Калі так, на веласіпедзе да салаўя

Паедзем - мая суседка і я ${ }^{8}$.

«Класічнае» беларускае аднарадкоўе таксама належыць А. Наўроцкаму:

Кваканне жаб заглушае спеў салаўя.

Гэта бліскучы прыклад нацыянальнага монаверша, або ўдэтэрона, мінімальнага па памеры тэксту, які валодае асабліва выразным патэнцыялам, магутнай мастацкай змястойнасцю. Філасофска-ёмістая інтанацыя гэтага монаверша А. Наўроцкага сугучна са з'явай парэміi, тэкст мае інтэнцыю да «разгортвання» тэкстава-паэтычнай адзінкі да разважанняў аб татальнай несправядлівасці светабудовы.

Трэба адзначыць, што уззоры ўдэтэрона як у айчыннай, так і ў рускамоўнай літаратуры сярэдзіны XX стагоддзя пераважна знайшлі ўвасабленне $\ddot{y}$ непадцэнзурнай літаратуры андэграйнду, дысідэнтаў і пісьменнікаў-эмігрантаў за кошт падкрэслена эксперыментальнага характару монаверша.

У 1970-я гады у беларускай літаратуры дзякуючы творчым пошукам Алеся Разанава з'яўляюцца нацыянальныя самабытныя малыя і мінімальныя лірычныя формы. Адной з разнавіднасцяў класічных мініяцюр у творчасці А. Разанава становіцца жанр пункціраў, які імкнецца да збліжэння з маляўнічымі эскізамі. Гэта максімальна кандэнсаваныя, кампазіцыйна простыя вершы, якія маюць рысы афарыстыкі. Эстэтыка мінімалізму, што праяўляе сябе ӱ вершах-пункцірах, дыктуе асаблівую стылістыку: тэкст ператвараецца ў накід, эксплікацыю «першасных структур», атамарных фрагментаў светабудовы:

8 А. Наўроцкі, Выбраныл творы, Мінск 2016, с. 17-18. 
Здасца, што ўсё ӱжо было:

позірк, пяшчотны і чулы,

сонца ў лісці і крыло,

што ӱвышыні мільганула ${ }^{9}$.

У творчай спадчыне Максіма Танка вылучаецца зборнік «Errata» (1996), дзе цыкл однастрофаў, створаных па мадэлі хоку, займае асаблівае месца. Эксперыментатар, наватар, паэт умела абыходзіцца 3 дадзенай малой паэтычнай формай, стварае атмасферу філасофскай засяроджанасці і тонкай эмацыйнасці. У вершах-хоку Макіма Танка асабліва ярка выявіла сябе майстэрства мастацкай дэталі:

Пацеркі пэрлаў -
сьлёзы асірацелых
рыбацкіх удоў${ }^{10}$.

У перыяд другой паловы XX стагоддзя $\ddot{\mathrm{y}}$ рускай літаратуры заяўляюць пра сябе прадстаўнікі неафіцыйнай паэзіі, майстры мастацкіх вакуум-тэкстаў Ры Ніканава, С. Сігей, Ул. Казакоў, М. Сапега. Адзін 3 самых вядомых тэкстаў Ры Ніканавай «Свабодны алфавіт» складаецца ўсяго з дзвюх літар, паміж якімі загадкавае Нішто, пазначаная адсутнасць:

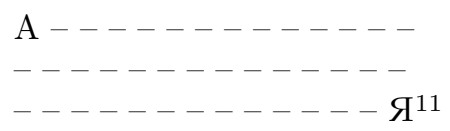

У тэкстах сусветнай нэаавангарднай канкрэтнай паэзіі Э. Яндля, О. Гомрынгера, Ф. Мона, М. Бензэ таксама адзначаюцца тэксты з рэдукцыяй фармальна значных кампанентаў. У вершы нэаавангарднага паэта-канкрэтыста О. Гомрынгера «Чорная таямніца» («das schwarze geheimnis») на старонцы літаральна намаляваныя абрысы нейкай скрыні, куфэрка, які, згодна 3 тэкстам, утрымлівае $\ddot{y}$ сабе «чорную таямніцу». Пустоты, вакуумныя лакуны, аформленыя ў вершы, не з'яўляюцца адсутнасцю знака або прыкметы, але семантычна і наўмысна структурна пазначаныя:

\footnotetext{
9 А. Разанаў, Танеи з вужакамі: выбранае, Мінск 1999, с. 68.

10 Максім Танк, Хоку [Электронны рэсурс], Рэжым доступа https://knihi.com/Mak sim_Tank/Choku.html, Дата доступа 12.09.2019.

11 Трансфуристыл. Избраннье тексть Рьг Никоновой, Сергея Сигея, А. Ника, Б. Констриктора, Москва 2016, с. 158.
} 


$\begin{array}{lr}\text { das schwarze geheimnis } \\ \text { ist } & \text { hier } \\ \text { hier } & \text { ist } \\ \text { das schwarze geheimnis } & \end{array}$

Па ступені колькаснага прырашчэння аб'ёму вылучаюцца тэксты з выкарыстаннем аднаго слова/знака, магчыма, паўторанага як аднаразова, так і некалькі разоў. Гэта творы Людкі Сільновай, Г. Ціханавай, Сержа Мінскевіча, А. Кавалеўскага у беларускай літаратуры, Ус. Някрасава ў рускай і Э. Яндля у нямецкамоўнай. У гэтай групе вершаў могуць знайсці рэалізацыю жанравыя прыкметы амбіграмы, паліндрома, лагагрыфа.

Так, асемантычныя эксперыменты з гукавой канстытуцыяй мінімалізаванага тэксту сустракаюцца ў творчасці Сержа Мінскевіча ў выглядзе вершаў-цыклафонаў, у якіх, пры шматразовым паўтарэнні, словаформы пераходзяць адна $\ddot{y}$ адну, як у вершы «Ваколіцы Браслава». Тэкст разлічаны менавіта на вакаральнае выкананне, пры якім і выяўляюць сябе кампаненты твора, адбываецца трансляцыя яго семантыкі:

БАРЫбарыбарыбарыБЯРЫбарыбаРЫБАрыбарыбарыБЯ РЫбарыбарыБАРЫ...

Замалёўку пра Браслаўскі край, што славіцца багаццем азёр і лясных угоддзяў, паэт засноўвае на вядомым лінгвістычным прыёме падваення для абазначэння множнасці, вялікай колькасці чаго-небудзь. За фармальным эксперыментам мінімалізіраванага тэксту лёгка згадваецца аповяд пра багацце роднага краю: пра вялікую колькасць «бароў», «рыбы», «рыбарой» і шчодрасці прыроды, перададзенай дзеясловам «бяры».

У творчасці Ус. Някрасава, аднаго з прадстайнікоў «ліанозаўскай школы», неафіцыйнай рускай літаратуры другой паловы XX стагоддзя, прыёмы паўтору, эканоміі лексічных сродкаў, выкарыстання паўзы як эквіваленту тэксту даволі распаўсюджаныя. Варта адзначыць, што сціплая колькасць знакаў у тэкстах гэтага паэта дазваляе выйсці на першы план інтанацыйнаму афармленню, гучанню слова:

12 Konkrete poesie. Deutschsprachige autoren. Antologie von E. Gomringer, Stuttgart 1996 , c. 77. 
Весна весна весна весна весна весна

Весна весна весна весна весна весна

Весна весна весна весна весна весна

И правда весна ${ }^{13}$

Лексічна многія творы тэарэтыка і практыка канкрэтнай паэзіі Э. Яндля зведзеныя да аднаго-двух параграфічных знакаў, што дэманструе крайнюю крытычнасць прадстаўнікой канкрэтызму ў адносінах да моўнага матэрыялу. Напрыклад, тэкст «Продак і нашчадак» («vorfahre und nachkomme») заснаваны на падвойным паўторы аднаго знака (літары), адрозніваюцца знакі толькі наяўнасцю кропкі пасля аднаго з ix:

Я.

$\boldsymbol{A}^{14}$

3 улікам адсутнасці ў іншых творах паэта традыцыйнай пунктуацы кропка ў гэтым вершы набывае дадатковую семантычную нагрузку, выказвае ідэю канчатковасці, здзейсненасці, такім чынам, перадае ідэю «продка». Адсутнасць знака прыпынку ў другім радку азначае наяўнасць будучыні, перспектыў, адмайленне абмежаванняў у «нашчадка».

Эфект абсурдысцкай нечаканасці і паўтору ляжыць у аснове так званых «Schüttelreime», кароткага жанру нямецкага фальклору і літаратуры, таксама распрацаванага $\ddot{\mathrm{y}}$ творчасці Э. Яндля. У вершы «о/і» гэтага аўтара абыгрываецца сітуацыя «сустрэчы» двух падобных слоў, момант якой дорыць чытачу магчымасць для асацыятыўнай працы:

$\mathrm{O}$

fr sch

$\mathrm{i}^{15}$

Беларускі аўтар Ганна Ціханава ў сваіх тэкстах-мініяцюрах не пераходзіць да эстэтыкі фарса, эксцэнтрыкі, а толькі вяртае паэтычнай

13 Вс. Некрасов, Стихи за десять лет, [Электронны рэсурс], Рэжым доступа http://www.levin.rinet.ru/FRIENDS/NEKRASOV/Stihi_za_10_let.html, Дата доступа 12.09.2019.

14 E Jandl, Künstliche baum, München 1997, c. 55.

15 Tамсама, c. 71. 
мове вастрыню і асэнсаванасць, дэманструючы нечаканую змену семантыкі пры захаванні фанетыкі. Двухрадковыя вершы з цыкла «Марскія шпількі» (1997) заснаваныя на паранімічнай гульні, могуць быць аднесены да такой формы верша, як гетэраграма. Радкі у падобным тэксце адрозніваюцца толькі расстанойкай прабелу:

\section{Новых твораў ніякіх не маю. \\ Новых твораў ніякіх - нямая. \\ Парушэнні дзеясловаў, \\ Парушэнні - дзея словаў ${ }^{16}$.}

Сучасны беларускі аўтар Аксана Бязлепкіна ўласным аднарадкоўем дае назвы, якія ўступаюць з тэкстам у адносіны эпіграматычнай нечаканасці. Так, тэкст з загалоўкам «Страснае» настройвае чытача на рамантычную хвалю, а аднарадкоўе насмешліва расчаройвае: «Аплявуха да самага вуха». «Спатканне ӱ кафэ» аказваецца зусім не прыемным рандэву, а драматычным прызнаннем лірычнай гераіні, стомленай ад адзіноты: «Я заплачу сама. Ты Толькі запрасі!». У сучаснай беларускай (Г. Ціханава, А. Бязлепкіна, В. Бурлак і інш.) і замежнай літаратуры (І. Губерман, В. Вішнеўскі, В. Арэфьева і інш.) цэлы шэраг аўтарай традыцыйна можа быць разгледжаны ў каардынатах катэгорыі камічнага.

Своеасаблівым аўтарскім крэда Рыгора Барадуліна ӱжо з першых публікацый сталі асаблівая рытмічная арганізацыя вершаў, унутраная рыфма, майстэрства гукапісу. Акрамя таго, гэтаму аўтару належыць тэкст «Паэма» (зборнік «Руны Перуновы», 2006), які складаецца $з$ пяці слоў, размешчаных у два рыфмаваныя радкі. Кампрэсія, зафіксаваная у гэтым паэтычным тэксце, дазваляе скараціць значную частку тэксту без істотнай страты для яго ідэйна-тэматычнага зместу. У тэксце выразна заяўлена драматычная мадальнасць, верагодна, лірычны герой апавядае пра складаныя адносіны 3 каханай, пра супярэчнасці, якія прывялі да тупіка ў адносінах і горкага жалю па згубленых пачуццях:

Мне цябе не стае $\mathrm{Tae}^{17}$.

Адзначым, што на ўсім працягу развіцця і функцыянавання сусветнага і айчыннага літаратурнага працэсу тэксты, якія імкнуцца да мінімалізацы, складалі не абшырны, але сістэмны корпус.

16 Друкапісы. Вялікая імправізацыя: паэзія, проза, Мінск 2009, с. 187.

17 Р. Барадулін, Рунь Перуновы: Выбраньяя творыл, Мінск, 2006, с. 43. 
У старажытны перыяд у беларускім літаратурным працэсе назіраюцца ў асноўным рыфмаваныя тэксты, якія працягваюць антычныя традыцыі эпіграм і эпітафій (А. Рымша, І. Легатовіч), а таксама развіваюць агульнасусветныя і нацыянальныя фальклорныя каноны прыказак, прымавак, мудрых максім (Ф. Скарына).

Ад старажытнасці да сучаснасці творы-мініяцюры, 3 аднаго боку, заснаваныя на разумовай і эмацыйнай канцэнтрацыі, а з другога - на кампрэсіі некаторых элементаў тэксту, дэлегуюць свае функцыі прадстаўленым у тэксце кампанентам.

Устанойлена, што абавязковай умовай функцыянавання падобных твораў у беларускай літаратуры на сучасным этапе часцяком становяцца механізмы атракцыі, парадаксальнасці, парушэння чаканняў чытача. Частка малых і мінімальных лірычных формаў маюць смехавую прыроду, імкнуцца да выкарыстання катэгорый камічнага, уключэння прынцыпаў эпіграматычнага завастрэння, прыёмаў гратэску i абсурдызацыі (творчасць А. Наўроцкага, паэтаў «найноўшага» перыяду - Сержа Мінскевіча, Г. Ціханавай, А. Бязлепкінай, В. Жыбуля, В. Бурлак і інш.). Тэксты-мініяцюры гэтых аўтараў у мінімальнай колькасці знакаў дэманструюць асаблівасці сучаснай смехавой культуры, дзе дакладна выяўляе сябе тэндэнцыя да амбівалентнасці смеху, які спалучае гумарыстычнае і філасафічнае, лёгкае і сур'ёзнае.

Акрамя таго, намі выяўлена, што у малых і мінімальных лірычных формах у беларускай літаратуры на працягу XX стагоддзя таксама ярка выяўляюць сябе рысы інтэлектуальна-філасофскай паэзіі, а таксама рамантычнай і імпрэсіянісцкай эстэтыкі і паэтыкі. Аўтары, ствараючы падобныя мінімалізаваныя творы, звяртаюцца да формаў лірычных медытацый, філасофска-інтэлектуальных разважанняў, імпрэсіянісцкай замалёўкі, заснаваных на драматычнай, а то і трагічнай мадальнасці. Асаблівым варыянтам такіх тэкстаў можна лічыць зварот беларускіх аўтараў да японскіх паэтычных мадэляў танка і хоку (М. Багдановіч, А. Наўроцкі, А. Разанаў, Рыгор Крушына, Максім Танк, Р. Барадулін).

\section{I T E R A T U R A}

Aleksandrovič A., Prozalac': veršy, Mensk 1926 [Александровіч А., Прозалачь: вершы, Менск 1926].

Baradulìn R., Runy Perunovy: Vybranyâ tvory, Mìnsk 2006 [Барадулін Р., Руньы Перуновы: Выбраныяя творы, Мінск 2006].

Drukapisy. Vâlikaâ impravizacyâ: paèzîa, proza, Mìnsk 2009 [Друкапісbl. Вялікая імправізачыя: паэзія, проза, Мінск 2009]. 
Haǔstovič M., Hìstoryâa belaruskaj litaratury 30-40-h hh. XIX st., Mìnsk 2001 [Хаўстовіч М., Гісторыя беларускай літаратуры 30-40-х ге. XIX cm., Мінск 2001].

Jandl E., Künstliche baum, München 1997.

Konkrete poesie. Deutschsprachige autoren. Antologie von E. Gomringer, Stuttgart 1996.

Naǔrocki A., Vybranyâ tvory, Minsk 2016 [Наўроцкі А., Выљраныя творы, Мінск 2016].

Nekrasov Vs., Stihi zadesât' let, [online], http://www.levin.rinet.ru/FRIENDS/NE KRASOV/Stihi_za_10_let.html, [dostup: 12.09.2019] [Некрасов Bc., Стихи за десять лет, [online], http://www.levin.rinet.ru/FRIENDS/NEKRASOV /Stihi_za_10_let.html, [доступ: 12.09.2019].

Razanaǔ A., Tanec z vužakami: vybranae, Mìnsk 1999 [Разанаў А., Танеu з вужакамі: выбранае, Мінск 1999].

Sajt Maksima Bagdanoviča, [online], https://www.maksimbogdanovich.ru/stories/ 286.htm, [dostup: 12.09.2019] [Сайт Максіма Багдановіча, [online], https: //www.maksimbogdanovich.ru/stories/286.htm, [доступ: 12.09.2019].

Skaryna F., Tvory: Pradmovy, skazannì, paslâsloǔi, akafisty, pashaliâ, Mìnsk 1990 [Скарына Ф., Творы: Прадмовы, сказанні, пасляслойі, акафісты, пасхалія, Мінск 1990].

Staražytnaâ belaruskâ̂ litaratura (XII-XVII stst.), Mìnsk 2007 [Старажbıтнаs беларуская літаратура (XII-XVII cmcm.), Мінск 2007].

Tank M., Hoku, [online], https://knihi.com/Maksim_Tank/Choku.html, [dostup: 12.09.2019] [Танк M., Хокy, [online], https://knihi.com/Maksim_Tank/Cho ku.html, [доступ: 12.09.2019].

Transfuristy. Izbrannye teksty Ry Nikonovoj, Sergeâ Sigeâ, A. Nika, B. Konstriktora, Moskva 2016 [Трансфуристы. Избранные тексты Рь Никоновой, Сергея Сигея, А. Ника, Б. Констриктора, Москва 2016].

\section{S U M M A R Y}

\section{SMALL AND MINIATURE LYRIC FORMS IN BELARUSIAN AND FOREIGN LITERATURE: HISTORICAL AND CULTURAL PERSPECTIVES}

The author of the article discusses the stages in creating aesthetics and poetics in small and miniature lyric forms in Belarusian and foreign literature from antiquity to modern times. On the basis of literature of various periods the author analyzes such forms as "vacuum poetry", texts with the reduction of formally significant components, texts with one word/sign repeated once or several times, udeterone, or single-liner, monopoem.

Key words: small and miniature forms, one-line form, mono line, udeterone, knowledge and study of aphorisms, attraction, Belarusian, Russian and Austrian literature. 